第 1 日 D 会場：皮質下徵候と正常圧水頭症 座長：西尾 慶之

I-D3-1 視床前部の脳損傷に伴う高次脳機能障害の特徵 -2 症例からの検討一

埼玉医科大学国際医療センターリハビリテーションセンター 星野 裕亮 鈴木 真弓 藤野 雄次 桑原 陽子 佐藤 茜 埼玉医科大学国際医療センター脳卒中内科佐野 博康 同 心臓リハビリテーション科牧田茂 同リハビリテーション科高橋 秀寿

〔はじめに〕視床前内側部に限局する脳損傷例において, 詳細な評価に基づく高次脳機能の特性や臨床経過は十分に明 らかではない。今回, 視床前内側部に限局した脳梗塞例の高 次脳機能の特徵について検討した。

〔対象〕視床前内側部に限局した急性期脳梗塞を認めた 7 例のうち, 詳細な高次脳機能評価をし得た 2 例を対象とし た。

〔方法〕入院時, 退院後の受診時に MMSE, FAB, Word fluency test, TMT, 仮名ひろいテスト, Digit span Test, RCPM, AVLT, WMS-R, RBMTを評価し, 高次脳機能の特 徵とその経過について後方視的に検討した。

〔結果〕症例 $1: 60$ 歳代男性。入院時 MMSE 19/30 点。 $\mathrm{FAB} 9 / 18$ 点。AVLT テストA2/4/5/6/6/2，テスト B2，再認 6 , 遅延再生 0 。WMS-R一般的記憶 55 , 言語 69 , 視覚 50 未 満, 注意 / 集中 79 , 遅延再生 50 未満。RBMT 標準プロフィ ール点 4 点, スクリーニング点 0 点。退院後 8 ケ月の再検査 においても前頭葉機能, 記憶力の低下は残存していた。症例 2:70歳代男性。入院時 MMSE 17/30 点。FAB 8/18 点。 AVLT テスト A3/5/8/7/6/5, テスト B1, 再認 4 , 遅延再生
0。TMTA 4 分 5 秒, B 4 分 18 秒。RBMT 標準プロフィール 点 2 点, スクリーニング点 1 点。退院後 3 ケ月の再検査にお いても前頭葉機能, 注意力, 記憶力の低下は残存していた。

〔考察〕視床前内側部の損傷例は, 前頭葉機能, 注意力, 記憶力が低下し，これら主症状の回復は遷延することが明ら かになった。視床前内側部は, 後交通動脈から分岐する視床 灰白隆起動脈と後大動脈起始部から分岐する傍正中視床動脈 により灌流され，それらの損傷によって papezの回路の障害 や，背内側核の損傷による前頭葉との神経連絡の障害により 記憶力, 前頭葉機能, 注意力の低下を呈していると考えられ た。一般的に個人差はあるが, 機能的な改善は難しく, 経過 も長期に渡ることから，早期から代償手段の獲得することが 推奨されている。その為介入早期から適切な評価をすること は, 残存機能の把握に加えて転帰や予後を予測する上で重要 であると考えられた。

I-D3-2 橋出血後の病的笑いに対するリハビリテーション

東京労災病院リハビリテーション科

東京女子医大大学院先端生命医科学研究所先端工学外科学分野 高倉 朋和

東京労災病院リハビリテーション科 鈴木久美子

同 中央リハビリテーション部 鈴木 志織 中野 由紀 同脳神経外科 竹林 研人

〔はじめに〕病的笑い (pathological laughter, 以下 PL) は, 橋・内包・線条体・小脳における脳血管障害, 多発硬化症, 脳腫瘍などにより生じる事が知られている。今回，橋出血後 にPLを生じた 1 例に対し，詳細な検討とリ八を行い良好な 経過に至ったので報告する。

〔症例〕 40 代男性

〔既往歴〕高血圧

〔現病歴〕突然の発声困難・手のしびれで発症し，高血圧 性橋出血の診断に対し保存加療が行われた。発症直後より 「笑いたくないのに笑ってしまう」と訴え,「面白い」「楽し い」という感情を伴わずに，吹き出すような笑いが頻回に認 められた。

〔現症〕左上下肢軽度失調と開鼻声を伴う軽度構音障害を 認めた。最長発声持続検査, 心理検査など心理的負荷が高ま る場面で，呼吸の変調を伴って PLが出現した。

〔神経心理学的評価〕意識清明 ·意思疎通良好, WAIS3 は $\mathrm{FIQ}=111 \mathrm{VIQ}=103 \mathrm{PIQ}=119$ と認知機能良好であった。

〔画像診断〕MRI では橋中間部の左背側から橋底部中央に かけ血腫 $(16 \times 21 \times 16 \mathrm{~mm}$, 約 $2.7 \mathrm{ml})$ を認め, DTI では橋 横線維の障害を認めた。SPECT では大脳・小脳に明らかな 血流低下を認めなかった。嚥下造影検査では, 発声時に軟口 蓋挙上不良・咽頭閉鎖不全を認め, 嚥下時にも息こらえが出 来ず, PLが出現した。

〔経過〕ブローイングや呼吸訓練を積極的に行って, 開鼻 声改善・随意的呼吸調節向上を図り，3 ケ月程で PL 症状は 改善して社会復帰に至った。

〔考察〕本症例におけるPLの機序として, 橋腹側部におけ る持続的呼吸抑制作用（荒田晶子, 自律神経, 2012）が障害 
された結果, 不随意な呼気が生じ横隔膜の振動に至るものと 推測した。また, “小脳を介した笑い/泣きサーキット説 (Parvizi et al, Brain 2001)” に当てはめて考える事が出来, 両側の皮質橋小脳路が障害されたために感情変化に対する情 動反応調節が困難となり, 過剩な情動反応が出力されて PL に至ること等が推察された。

\section{I-D3-3 橋出血後に幻視と幻触を呈した一症例}

社会医療法人春回会長崎北病院総合リハビリテーション部 山田 麻和

同 神経内科

佐藤 秀代

佐藤 聡 辻畑 光宏

〔はじめに〕脳幹病変による幻覚は橋出血による場合が多 く, 橋出血の生存例の $47 \%$ に認めるとの報告がある（Nakajima 1983)。今回, 幻視と幻触を伴う高血圧性橋出血の患者 を担当したので報告する。

〔対象〕54歳男性, 右利き, 教育歴 16 年。喘息治療のため 他県の病院に入院中に脳出血を発症し, 保存療法後 33 日目 に当院転院となった。

〔神経学的所見〕左右上下肢に運動失調を認め, 左に Br.stage 上肢 III 下肢 IV 手指 III の麻痺を認めた。視野では右 に水平方向の眼球運動障害, 左に外転時眼振を認めた。左表 在感覚は上肢・体幹重度鈍麻・下肢脱失, 左深部感覚は上下 肢体幹共に重度鈍麻であった。

〔神経心理学的所見〕 MMSE 27/30, HDS-R 29/30, FAB 16/18, RCPM 34/36, Digit span 順唱 9 逆唱 6, 三宅式記銘 力検查有 $9-10$ 無 $5-9-10$ 。知的・記憶 - 注意面での低 下なし。

〔幻覚・幻触〕介入 3 日目に左半身に 4 個, 右半身に 3 個, 肌色をした何か (生物) が身体全体を覆っていると話し, 自 身にしか感じない事に気づく様子も見られた。1 週目には形 が具体化し「アンドロイド」と述べ，頻繁に身体を吒き追い 払おうとする行為あり。経過と共にアンドロイドの数は 5 個 に減り，覆われる部位も左半身と体幹部に限定した。症例は 夜間不眠を認め, 幻触は昼夜共に出現し対話しているように 話す場面も見られた。発症から約 2 ケ月で幻視は消失し，幻 触は発症から 7 ケ月後の退院時も持続していた。

〔画像所見〕橋右傍正中, 底部背側から被蓋におよぶ $2 \mathrm{~cm}$ の早期慢性期血腫と左外側後頭葉皮質下に $1 \mathrm{~cm}$ の早期慢性 期血腫あり。

〔考察〕脳幹病変による幻覚は peduncular hallucinosis と呼 ばれ, 幻視が主体で幻聴を伴わず短期間であることが特徵と される。幻触の報告は散見される程度であるが, 山口(1991) や橋本（1995）らの報告同様, 本例でも被蓋部中心の病巣を 呈しており, 要素的感覚障害と上行性網様体賦活系の両者の 障害との関連性が伺えた。

\section{I-D3-4 視床出血における遂行機能障害出現に関与する要 因 -2 症例間での検討一}

香川大学医学部附属病院リハビリテーション部

池内英里菜 黒川 清博
川崎 未来 久保潤一郎

香川大学医学部脳神経外科 河井 信行

〔はじめに〕視床出血において遂行機能障害が生じること は多いとされているが, その症状について左右損傷別で検討 した報告は少ない。今回, 当院高次脳機能障害外来にて出血 量が同程度の視床出血例 2 例に対し, 遂行機能障害症候群の 行動評価日本版（以下 BADS）をはじめとする高次脳機能評 価を実施した。その結果, 左視床出血 (左側例) と右視床出 血（右側例）でBADS の成績差を認めたため, 遂行機能障害 へ影響を与える要因について検討した。

〔症例 1〕50 歳女性。左視床出血：出血量 $10.5 \mathrm{cc}$ 失語症状 なし（発症 8 か月後に評価）

WMS-R 言語性 64/視覚性 50/一般的 54/注意 集中力 71 / 遅 延再生 50 未満, BADS 標準化得点 28 点, CAT cut off 点以 下：逆唱 2 桁 / 聴覚性抹消検出検査 $52 \%$ /SDMT $35 \%$ / PASAT 2 秒 : $23 \%, 1$ 秒 : $26 \%$ / 上中下検査 $66 \%$

〔症例 2〕 47 歳男性。右視床出血 : 出血量 $9 \mathrm{cc}$ (発症 7 か月 後に評価)

WMS-R 言語性 80/ 視覚性 50 未満 / 一般的 58/注意 集中力 $66 /$ 遅延再生 50 未満, BADS 標準化得点 80 点, CAT cut off 点以下：逆唱 4 桁/Tapping Span backward 3 桁 /PASAT 2 秒 : $27 \%, 1$ 秒 : $8 \%$ / 上中下検査 $0 \%$ （拒否）

〔考察〕今回, 左右同程度の出血量である視床出血の 2 例 に対し, 各種神経心理学的検査を実施した結果, BADSにお いて 2 例間に著明な差を認めた。WMS-Rの結果から, 両側 とも全般的な記憶機能の低下を認め, 左側例では右側例と比 較し，より言語性記憶の低下を認めた。CATより両側とも ワーキングメモリ（以下 WM）の低下を認めたが, 左側例で はより全般的な注意機能の低下を認めた。以上の結果から, 左側損傷では失語症状を認めない例でも言語性記憶や全般的 な注意機能の低下により, 遂行機能障害がより重度化しやす く, BADS の成績に乘離が生じたと考えられる。行動計画能 力には WM の能力が影響するとされているが, 遂行機能に はWM 以外にも言語性記憶や全般的な注意機能が影響する 可能性が考えられる。

\section{I -D3-5 iNPH 患者の認知機能に関する検討 — TMT の完 遂に着目して一}

洛和会音羽病院リハビリテーションセンター＼cjkstart松元 雅俊

江口瑠美子 萩尾 敦史 洛和会音羽病院リハビリテーション科田中尚 洛和会音羽病院高次脳機能障害センター 猪野 正志 洛和会音羽病院正常圧水頭症センター 石川 正恒

〔はじめに〕iNPH の認知機能の先行研究では Miyoshi ら （2005）や大㭇ら（2006）等による検討があるが, 多人数での 検討は少ない。当院では MMSE, FAB, TMT-A/B（横版） を実施しているが, Dr.の効果判定と認知機能検査の結果の 不一致例を度々経験する。当院の TMT の結果は, A の術前 後の完遂例が約 2 年間 56 症例中 41 例 $63 \%$ あったこの中で 術後 A が $30 \%$ 向上したのは 9 例（16\%）であった。Bの術前 後の完遂例は約 2 年間 56 症例中 14 例 $(25 \%)$ であった。こ 
の中で術後 B が $30 \%$ 向上したのは 3 例 (5.3\%) であった。又 術前にAが完遂し B が完遂不可であった例が, 術後可能とな った例は 11 例（19\%）あった。

〔目的〕䯣液排除実施前と排除実施後における TMT-A/B の完遂と MMSE，FAB 下位検查項目の変化について関連性 を検討。

【対象】画像診断等から iNPH と診断された 56 例（シャン 卜術を未施行例も含む）を対象とした。平均年齢 $77.7 \pm 6.0$ 歳, 男性 33 名女性 23 名, 入院期間 1 週間 1 力月半程度。

〔方法〕 TMT-A/B について術前後にそれぞれが完遂でき たかどうかで 4 群に分類した。グループは 1. が 16 例で平均 年齢78.9 歳。 $\mathrm{A}$ 術前術後 $\bigcirc / \mathrm{B}$ 術前術後 $\times$ 。2. が11 例で平均 年齢77.2 歳。 $\mathrm{A}$ 術前術後 $\bigcirc / \mathrm{B}$ 術前 $\times$, 術後 $\mathrm{O}$ 。3. が 14 例で 平均年齢 74.1 歳。 $\mathrm{A} / \mathrm{B}$ 術前術後 $\mathrm{O}$ 。 4. が 15 例で平均年齢 79.9 歳。 $\mathrm{A} / \mathrm{B}$ 術前術後 $\times$ とした。比較する MMSE，FAB の下位 検查項目は Serial7, 語の流暢性, 系列運動, 葛藤指示, Go/ No-Go で検討。 $\chi 2$ 検定を用い，有意水準 $\mathrm{p}=0.05$ とした。

〔結果〕Serial7, 系列運動, 葛藤指示, Go/No-Go では有 意差一。語の流暢性のみ 2. で有意差十。

〔考察〕視覚性注意と運動機能が一定程度保たれている症 例で，術後にTMT-Bが可能となった 11 例と語の流暢性との 関連で有意差を認めた。これは術後に遂行機能や作動記憶, 思考の柔軟性の改善を示唆しており, 比較的早期から前頭葉 機能の改善が現れていると捉えられる結果と推測した。 iNPH に扔いて, 遂行機能や作動記憶に着目することの有用 性を示していると考える。

\section{I-D3-6 特発性正常圧水頭症における補助診断としての FDG-PET および PIB-PET の役割}

香川大学医学部脳神経外科

池内英里菜 黒川 清博

川崎 未来 久保潤一郎

香川大学医学部脳神経外科

〔はじめに〕高齢者における治療可能な認知症の一つに, 特発性正常圧水頭症 (iNPH) があり, シャント手術後 1 年の 時点で $80 \%$ の症例で日常生活活動の改善が認められると報 告されている。しかし iNPH は高齢者に多く，アルッハイマ 一病 $(\mathrm{AD})$ の合併が多く見られ，手術適応の決定に難渋する こともある。我々は iNPH が疑われた症例に対し，ブドウ糖 代謝を調べる FDG-PET と AD の特徵的な病理所見であるア ミロイド沈着を調べる PIB-PETを施行し補助診断としての 有用性を検討したので報告する。

〔対象と方法】臨床症状㧍よび画像検查で iNPH が疑われ た患者 23 名 (男性 11 名, 女性 12 名, 年齢 $59 \sim 82$ 歳, 平均 $73.7 \pm 6.1$ 歳）を対象とした。FDG-PET は全症例に施行し, 統計学的画像解析ソフト $3 \mathrm{D}-\mathrm{SSP}$ を用いて正常被験者群と比 較して個々の患者において糖代謝が相対的に低下ないし充進 した部位を検出した。またPIB-PET 検查は最近の 10 症例に 施行し, 小脳を reference として大脳皮質の binding potential
（BP）を画像化した。

〔結果〕Tap test が陽性で probable iNPH と診断された症例 は 9 例であり, 内 6 例にシャント手術を行い症状の改善を認 めた。Probable iNPH と診断された症例は, シルビウス裂周 囲の相対的な糖代謝低下と内側前頭頭頂葉（傍中心小葉）に おいて相対的な糖代謝光進を認めた。残りの症例は, 後部带 状回や頭頂側頭連合野などに相対的な糖代謝低下を認め, $\mathrm{AD}$ が主体の認知症と診断した。またPIB-PET検查を行った 10 例中 5 例に前頭葉を中心とした大脳皮質に PIB の集積を認 めた。

〔結論〕 iNPH は， AD など他の認知症性疾患を合併する頻 度も高いため, FDG-PET や PIB-PET を併用した補助検查 は，除外診断や informed consentを行う際に有用である。ま た iNPH 症例に認められた内側前頭頭頂葉の相対的な糖代謝 充進は, 高位円蓋部の脳溝狭小化と関連した診断に有用な所 見であると思われる。 